\title{
Religious Communal of Indigenous Peoples in Improving Economy Through Local Wisdom (A Juridical Study on Rural Credit Institution in Bali)
}

\author{
Johannes Ibrahim \\ Faculty of Law, Maranatha Christian University \\ Jl. Prof. Drg. Surya Sumantri No.65, Bandung, 40164, West Java, Indonesia. \\ Tel./Fax: +62-22-2012186E-mail: hassanain.haykal@gmail.com \\ Hassanain Haykal \\ Faculty of Law, Maranatha Christian University \\ Jl. Prof. Drg. Surya Sumantri No.65, Bandung, 40164, West Java, Indonesia. \\ Tel./Fax: +62-22-2012186 E-mail: hassanain.haykal@gmail.com \\ Submitted: Jan 7, 2016; Reviewed: Mar 2, 2016; Accepted: Mar 26, 2016
}

\begin{abstract}
Rural Credit Institution is a financial institution that is specifically located in Pakraman (customary villages) in Bali. The presence of Rural Credit Institution in Bali adjoined to other bank financial institutions such as Commercial Banks and Rural Banks are widespread throughout the province of Bali. Rural Credit Institutions as a financial institution acquire legality under Article 58 of Act No. 7 of 1992 in conjunction with Act No. 10 of 1998 which provides status as Rural Banks. Local wisdom that owned by Rural Credit Institutions, has the scope of business activities, the types of activities and financial transactions are limited in Pakraman as the target area. Customers who save funds or require a loan to be registered as local residents aimed at empowering communities. It is a characteristic of religious communal of Bali's people for business activities in the village. The uniqueness in the Rural Credit Institutions is the local wisdom of Bali's people that can be maintained and not be crushed by globalization.
\end{abstract}

Keywords: Customary Villages; Indigenous Peoples; Local Wisdom; Rural Credit Institution

DOI: http://dx.doi.org/10.20956/halrev.v1n1.216

\section{INTRODUCTION}

Indonesia is a country that consists of various tribes, where each tribe has their custom. Custom is a reflection of the personality of a nation, as the embodiment of the soul of nation over the centuries. Custom is behavior by and within a society. Furthermore, a custom, there are thick, thin and always thickened and thinned. The rules of human behavior in society as mentioned earlier are customary rules. But from the rules of behavior, there are also rules of behavior that is the rule of law. ${ }^{1}$ Customs alive and processes related to the tradition is a source for customary law. ${ }^{2}$ One style of Indonesian customary law in contrast to Western law

\footnotetext{
I Soerojo Wignjodipoero. (1983). Pengantar dan AsasAsas Hukum Adat. Jakarta: Gunung Agung, p. 21 2 Ibid., p. 13
} 
that is individualistic-liberalistic has the characteristic of togetherness or strong communal, it means that human beings according to customary law as creature in a close community, a sense of community is covering the entire of customary law. ${ }^{3}$

The style of togetherness in customary law meant that the customary law takes precedence over common interests, in which self-interest covered by a common interest. One for all and all for one, the legal relationship between members of the indigenous communities was based on a sense of togetherness, kinship, helping each other and mutual cooperation. ${ }^{4}$ Even the style and nature of togetherness is also raised in Article 33 paragraph (1) of the Constitution 1945 which states that "the economy is arranged as a joint venture based on the principle of kinship." In the explanation saying that, in Article 33 are contained on economic democracy, production is done by all, for all under the leadership or ownership of the community members. Prosperity for communities to come first, not the individual. Therefore, the economy is arranged as a joint venture based on the principle of kinship. ${ }^{5}$

However, with the development of globalization, custom and community in it (indigenous people) remained alive. This is as stated by Soerojo Wignjodipoero ${ }^{6}$ that the level of civilization, and the means of modern life was not able to eliminate customs that live in the community, at least seen in the progress of the times, that such custom

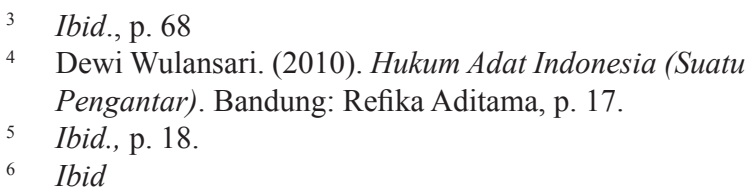

adjust to the situation and era, so the custom was to be permanent and stays fresh. As described above, can be seen in the current era of globalization, where the influence of customs and cultural are still remains.

According to Anthony Giddens, globalization is the intensification of worldwide social relations linking distant localities in such a way that local events are affected by events that occur across distant and vice versa. Globalization demolish the spatial and time concepts that led to the restructuring of the governance in depth, almost in every aspect of life, starting from the West and then hit all parts of the world. ${ }^{7}$ In the academic world, the word of Globalization is a word that is already familiar.

Theoretically, this globalization involves three interrelated things, first is the issue of transformation, the second is cultural and the third is economic. The transformation of local people into the world people that resulting the weak of states' role. The world becomes large village without boundaries. This is the era that by Kenichi Ohmae called the end of the era of the nation state. According to Ohmae, there are four factors that affect the role of the State. First is investment, the second is industry, the third is information technology, and the fourth is the individual consumer. ${ }^{8}$

One of the customs that still survive in the life of indigenous peoples of Indonesia is customary related to the community's

Source: Ampenan News. Quoted from website: http:// ampenannews.com/eksistensi-budaya-indonesiadalam-arus-globalisasi/. Accessed on 24 November 2015, at 11.44 WIB.

8 Konichi Ohmae. (1995). The End of the Nation State the Rise of Regional Economics. London: HarperCollinsPu-blishers, p. 1-4. 
economy, particularly in the areas of financing, such as Rural Credit Institutions in Bali and Lumbung Pitih Nagari in Padang, the financing model that was developed based on the values of indigenous peoples living in the community in order to help the economy. Bali is one of the provinces in Indonesia which is famous for its culture. One of the unique in Bali is the existence of Pakraman. The scope of Pakraman village is not limited to the roles of social, cultural and religious, there are also economic role to manage Pakraman village.

The Rural Credit Institutions (hereinafter LPD) as a business entity the Saving and Loan owned by the customary village and serves to promote the economic development of rural communities through targeted savings as well as the effective capital distribution. LPD has a role as an institution whose role is to improve the peoples' prosperity through a populist economic development, in addition to LPD as a source of revenue indigenous villages, because $20 \%$ of profits obtained LPD dedicated to promoting the empowerment of indigenous villages. The presence of LPD in Pakraman has been able to increase the potential of the community and assist them, and eliminates the burden on the people. The role of LPD in assisting the community of Pakraman is also included in providing funds to build the temple and the ceremony, which was previously done with private funds of Pakraman's people. ${ }^{9}$

Post-enactment of Act No. 1 of 2013 on Micro Finance Institutions, where LPD

\footnotetext{
LPD Bali. Quoted from website: http://lpd-bali.com/ category/profil/tentang/. Accessed on 27 November $\underline{2015}$, at $16.09 \mathrm{WIB}$
}

(Rural Credit Institutions) is recognized its presence as financial institutions that are specialized so that the arrangements are exempt from the Act. This is confirmed in Chapter XIII Transitional Provisions of Article 39 paragraph (3), that: "The Rural Credit Institutions and Lumbung Pitih Nagari and similar institutions that had existed before this Act prevail, stated "it is recognized by customary law."

\section{METHOD}

The method of research used in this study is juridical-normative with the type of study that takes literature data. A juridicalnormative research, as the main research is a literature legal research. In this study, the library materials are a basic data classified as secondary data. The nature of research used in this research is descriptive, that is by trying to give a description of the actual problems based on the facts. Furthermore, the methods of research used in accordance with the formulation of problem as the focus of this research. The approach method used in this study is the conceptual and legislation approaches.

A juridical-normative research is using secondary data. In the legal research, secondary data includes the legal materials of primary, secondary, and tertiary. The analysis technique used is a qualitative approach. In this qualitative approach, do not use statistical parameters. Deductive method is used for the data obtained from the literature search, whereas the inductive method is used for the data obtained from the field and complementary in this study. 


\section{ANALYSIS AND DISCUSSION}

The Urgency of Financial Institutions in

\section{Community Trade System}

Indonesia's financial system in principle can be divided into two types, namely the banking system and non-bank financial institutions. The characteristics of the most dominant financial sector that can be observed are so rapid changes taking place in it along with the rapid growth in the economy. Policies in the fields of finance, monetary, and banking from time to time need to be adjusted to follow the dynamics of the economy as the impact of globalization in which the changes in a country's economy, especially the developed countries, would have an impact on other economies, especially in activities the stock market of a country.

The financial system is one of the most crucial designs in this modern time. It is not inconceivable, if all of the financial activities of an institution with other financial institutions, as well as between one country to another, made without the mediation of a financial system which is good, then all financial transactions that take place will not be arranged due to uncoordinated well. The payment system and intermediation may be accomplished without the financial system.

The financial system can be defined as the set of institutions, market, legislative provisions, regulations, and techniques in which the securities are traded, the interest rate is set, and financial services is produced and offered to all parts of the world. ${ }^{10}$

10 Dahlan Siamat. (2005). Manajemen Lembaga Keuangan, Kebijakan Moneter dan Perbankan. Fifth editions. Jakarta: Faculty of Economics University of Indonesia, p. 1; Peter S. Rose. (1997). Money and Capital Markets. Financial Institution and Instruments in a Global Marketplace, $6^{\text {th }}$ Editions. Texas A \& M University.,
The financial system in modern economies has at least 7 (seven) the principal functions, as follow: ${ }^{11}$

1. Function of savings, the financial market system and financial institutions to provide instruments for savings. Bonds, stocks and other money instruments traded in the money market and capital market which promises an income and with low risk to the community of savers flowing through financial markets then used for investment so that goods and services can be produced.

2. Functions of asset custody, the financial instruments traded in the money market and capital market provides a good way to store wealth (i.e hold the value of assets in the possession) until the funds needed to be spent.

3. Function of liquidity, the wealth stored in the form of financial instruments can be easily availed through the mechanism of the financial markets. Bonds or stocks and other financial instruments promising profit with relatively small risk. The money market and capital market provides a way to convert these instruments into cash. Depository financial institutions provide a variety of alternative savings instruments that have high liquidity.

4. Function of credit, the financial markets provides credit to finance consumption and investment in the economy. Credit is a loan that is accompanied by a promise to pay back in the

11 Quoted from website: https://titikcute.wordpress.com/ sistem-keuangan-indonesia-berbasis-pasar-atau-bank/. Accessed on 2 September 2015, at 10.00 WIB. 
future. Consumers need credit to buy goods such as houses, cars and so on. While employers use credit facilities (credit line) to purchase goods for the purpose of production, building, buying machinery, paying salaries or dividends to shareholders, and so on.

5. Function of payment, the financial system provides a mechanism payment for transactions of goods and services. Payment instruments include checks, giro slips, credit cards, including the clearing mechanism in banking.

6. Function of risk, the financial markets offers to the business units and consumers protection against life, health and the risk of income or loss. This can be done by selling various insurance policies.

7. Functions of policy, the financial markets have become the principal instrument that can be used by governments to undertake policies to stabilize the economy and affect inflation through monetary policy.

These financial institutions can accept deposits from the public, it is also called depository financial institutions consisting of commercial banks and rural banks. Meanwhile, non-bank financial institutions are financial institutions other than banks in their business activities are not allowed to collect funds directly from the public in the form of deposits.

In the history of the development of Indonesia's financial system, the financial institution system changed very fundamentally, especially after entering the era of deregulation, October 27, 1988 policy package which then continues with the enactment of several laws in the field of finance and banking since 1992, namely: Act No.7 of 1992 concerning Banking; Act No. 2 of 1992 concerning Insurance; Act No. 11 of 1992 concerning Pension Fund; Act No. 8 of 1995 concerning Capital Markets; Act No. 23 of 1999 concerning Bank Indonesia; and Act No. 21 of 2011 concerning the Financial Services Authority.

Consequences of the issuance of these Acts are a change in the structure of the system of financial institutions in Indonesia. In addition, from the aspects of managing and developing, financial institutions became increasingly clear and strong as it has legal force.

The financial institution is any company engaged in finance, raise funds, funds or both. Theoretically, there are two kinds of financial institutions are bank and nonbank financial institutions. The main roles of these two institutions are relatively similar; as financial intermediation between ultimate lenders with ultimate borrowers.

\section{Financial Institutions in Indigenous Peoples in Indonesia \\ Credit Institutions of Pakraman}

Since it was first proposed in 1984, where Rural Credit Institutions (hereinafter called LPD/Lembaga Perkreditan Desa) is proven to improve the welfare of rural communities and supporting the growth and development of the culture of Bali as the nations' assets. LPD not only plays its function as a financial institution that serves the financial transactions of rural communities but has also become a solution to limited access to 
funding for rural communities that in fact is a group of people with limited economic capacity. ${ }^{12}$ LPD's success is the result of the concept of establishment and management of LPD from local wisdom and Balinese cultural based on solidarity, kinship and cooperativeness (sekaa).

Although the idea of establishing LPD comes from Local Government of Bali (Governor Prof. IB Mantra), but actually the idea was obtained of something that has evolved as a culture and local wisdom of Bali. That is, the idea of LPD actually rooted in the customs and culture of Bali. Cause LPD's success also comes from the pattern of community-based management with a foundation of family values and cooperativeness in the frame of the customs and culture of Bali. Communities in Pakraman are the owner and manager of the LPD that performing task and its function in commitments to achieve prosperity and progress together. ${ }^{13}$

LPD as an important asset Bali because its function is very fundamental to support the customs, culture and social life of the people of Bali. The supporting of customs, culture and social life of the people of Bali is the hope not only of Balinese but also the Indonesia nation. Customs, culture and Balinese's life is an asset as well as potential of the Indonesian nation.

After 26 years, LPD serves as kamad$h u k$, as cows that produce milk so Pakraman can keep the customs, culture and traditions of Bali, appears miscellaneous thoughts on

\footnotetext{
12 Quoted from website: http://www.balisaja. com/2011/02/lpd-penyangga-adat-dan-budaya-bali. $\underline{\mathrm{html}}$. Accessed on 27 November 2015, at 17.00 WIB.

13 Ibid.
}

LPD. Quite a lot of it is thought to maintain the regularity LPD. But not infrequently also thought to dwarf the LPD, because LPD is considered as a competitor. Not a few who realize the great power of Pakramana that supported LPD so need attenuated for certain political purposes. ${ }^{14}$

\section{Pitih Nagari Institution}

Nagari is part of the identity and the basis of Minangkabau's community life, West Sumatera. Implementation of Act No. 5 of 1979 concerning Village Government, which changed Nagari become village, considered a form of "javanism" which has reanimate the social relations, identities and local leadership powers. After the reform, the concept of Nagari rises and increasingly upset with the slogan "back to Nagari."15

Nagari have a set of traditional mechanisms to regulate all forms of social relations, such as the system of government, economic, human relationships and the relationship between humans and nature. Nagari governed by the principle of tali tigo sapilin: the linkage between customary law, sharia Islam, and state law (positive law, Act). Special relationship between indigenous and Islam, the people of Minang adhering to the principles of customary Basandi Syarak, Syarak Basandi Kitabullah (or abbreviated as ABS and SBK), to organize and create a balance between human, nature, and God. Nagari autonomous government held collectively by the principle of tigo tungku sajarangan (ninik mamak, clergy, and intellectu-

14 Ibid.

15 Muhammad Adlin Sila. (2010). "Lembaga Keuangan Mikro dan Pengentasan Kemiskinan: Kasus Lumbung Pitih Nagari di Padang." Jurnal Sosiologi Masyarakat FISIP-UI. Vol . 15, No. 1, p. 9. 
al), and decisions made through deliberation between the leader and his people in Nagari. One of the blessings of the slogan "back to Nagari" is the presence of micro-credit institutions Lumbung Pitih Nagari (LPN), it is means as a place to collect money belonging to Nagari.

\section{Rural Credit Institutions (LPD) as Finan- cial Institutions of Indigenous Peoples in Bali}

Rural Credit Institutions (LPD) is a form of economic institutions belonging Pakraman ${ }^{16}$ regulated in special regulation. The regulation is the Bali Provincial Regulation No. 8 of 2002 on Rural Credit Institutions, Bali Provincial Gazette No. 20 of 2002, and Supplement Gazette of Bali Provincial No. 3 (hereinafter referred to as LPD Regulation No. 8/2002), as amended 2 (two) times with

16 Pakraman village is a traditional institution and is known since the empire and its existence and developing well preserved until today. The term of Pakraman village in Bali is also known by the name of Dresta village or Indigenous village, which has an area or scope of a few village/ neighborhood/village Department headed by the village chief. But do not rule out the possibility of the village of Department consists of several Pakraman village. This village is the unity of indigenous people in Bali which have a unity of tradition, manners in social life and social customs of different legal bond between one village to another. Pakraman have ties hereditary in Kahyangan Tiga consisting of Pura Desa, Puseh and Dalem Setra, have certain areas, assets, land belonging to the village, so there is termed tanah ayah desa (communal land occupied by local residents) and reserves the right to take care of his own household. The concept of establishment of Pakraman is very noble indeed, aim to unite the people of Bali, the idea was conceived and formed by Mpu Kuturan in Isaka 932 (1001 AD) through meetings known as Samuan Tiga, and when it is formed and the establishment of Pakraman. In its development after the occupation of the Netherlands, there is a term traditional village developed into the Indigenous Village, and the meaning of the customs and Pakraman become blurred there is still ambiguous and confused, so that by the time the reform in 2003, the term of Pakraman returned its existence and return to the original concept, so that Indigenous villages, Pakraman and Dresta it is one with different terms to other village.
Local Regulation of Bali Provincial No. 3 of 2007 on the Amendment of local regulation of Bali Provincial No. 8 of 2002 on Rural Credit Institutions, Bali Provincial Gazette No. 3 of 2007, Supplement Gazette of Bali Provincial No. 3 (hereinafter referred to as LPD Regulation No. 3/2007), and the Local Regulation of Bali Provincial No. 4 of 2012 on the Second Amendment of Local Regulation of Bali Provincial No. 8 of 2002 on Rural Credit Institutions, Bali Provincial Gazette No. 4 of 2012, Supplement Gazette of Bali Provincial No. 4 (hereinafter referred to as LPD Regulation No. 4/2012).

Based on Article 2 point 1 of LPD Regulation No. 8/2002, states that: "Rural Credit Institutions (LPD) is a village-owned financial enterprise conducting activities in the village and for rural karma".

The provisions in Article 2 point 1 of LPD Regulation No. 8/2002 indicates that the LPD is a form of economic institutions that are recognized and affirmed by the decision in the legal status as a form of financial business entity. The business entity of LPD is special because only undertake business activities in the region of Pakraman. ${ }^{17}$

LPD as financial entities that are specific business activities as stipulated in Article 7 paragraph (1) of Local Regulation No. 8/2002, which include: a) receive and collect funds from rural karma in the form of financial and deposits; b) giving a loan only to rural karma; c) receive loans from financial institutions to a maximum of $100 \%$ of the total capital, including reserves and

\footnotetext{
17 I Nyoman Nurjaya et. al. (2011). Landasan Teoritik Pengaturan LPD (Sebagai Lembaga Keuangan Komunitas Masyarakat Hukum Adat Bali. Denpasar: Udayana University Press, page. 36.
} 
retained earnings, unless other limits on the amount of loans or support/assistance funds; and d) saving excess liquidity in BPD with interest to compete and adequate services.

Based on the substance of Local Regulation of LPD No. 8/2002, shows that LPD is a specialized financial entity. The characteristics of LPD as a specialized financial institution as follows:

a. Owned by Pakraman village;

b. Formed and managed by Pakraman village;

c. Organizing functions of Pakraman's community financial institutions, such as receive/collect funds from rural karma, giving a load to rural karma, and manage the financial institutions, only on Pakraman's environment, and

d. Conducting business as a function of internal financial business institutions of Pakraman, or between Pakraman village. $^{18}$

\section{Religius Communal in Rural Credit Institutions (LPD) in Bali as a Form of Local Wisdom}

Act No. 10 of 1998 on the Amendment of Act No. 7 of 1992 concerning Banking has accommodated the various of financial institutions that already exist in society with different characteristics. This is as stated in Article 58 of Act No. 7 of 1992 which states:

"Rural Bank, Village Office, Market Bank, Employee Bank, Lumbung Pitih Nagari (LPN), Lembaga Perkreditan Desa (LPD), Badan Kredit Desa (BKD), Badan Kredit Kecamatan (BKK), Kredit Usaha Rakyat Kecil (KURK), Lembaga Perkreditan Kecamatan (LPK), Bank Karya Produksi
Desa (BKPD) and/or other institutions equivalent to the given status as Rural Credit Bank based on this Act to meet the requirements of the procedures stipulated by government regulation."

In the explanation of Article 58 of Act No. 7 of 1992 explained that given the institutions referred to in this Article has grown and evolved from Indonesian society, and still needed by the communities, then the existence of such institution recognized. Therefore, this Act provides clarity on the status of the institutions in question. Furthermore, to ensure the unity and uniformity in developing and supervision, then the Government Regulations set out the requirements and procedures for granting the status of the institutions referred to as Rural Credit Bank.

Rural Credit Institutions (LPD) as a traditional financial institution has a strong characteristic or communal and togetherness, it is evident from its characteristics, namely: a) scope of business; b) not in competition; c) restricted operational areas; and d) the role of the village head of customs and policies discussed along with other Pakraman.

LPD which formed the basis of communal and togetherness, in the opinion of the author has a very clear mission, which is helping to develop the business and empower communities through loans or financing, deposit management, as well as the provision of consulting services for business development is not solely for profit. Considering one of the characteristics that zoning restrictions, loan or financing provided by LPD can be categorized as loans or micro-scale financing. 
In general, the operational activity of LPD in line with the "spirit" or Microfinance foundation is regulated by the Government. It is as set forth in Act No. 1 of 2013 on Micro Finance Institutions, i.e to develop the economy of the people become strong, powerful, and independent, which cause an increase of the national economy shall be organized based on economic democracy with the principles of togetherness, efficiency with justice, sustainability, environmental friendliness, independence, and balancing economic progress and national unity.

LPD's existence needs to be maintained, even developed not only in Bali, but can also be developed in various regions in Indonesia and brought cultural values and local wisdom respectively. Development of LPD such as microfinance is wide open, given the microfinance regulated by the Government of more advanced aspects of nationalism without foreign interference, as stated in Article 8 of Act No. 1 Year 2013 on Micro Finance Institutions stating that Microfinance Institutions can only belong by:

a. Indonesian citizens;

b. Rural-owned enterprises;

c. District/city Government; and/or

d. Cooperative

However, in the conduct of business, Microfinance Institutions have restrictions or prohibitions referred to in Article 14 of Act No. 1 of 2013 on Microfinance Institutions, namely:

a. Accepting deposits in the form of demand deposits and participate in payment transactions;

b. Conducting business in foreign currency; c. Conducting business in insurance as an insurer;

d. Acting as guarantor;

e. Lending or financing to other Micro Credit Institutions, except in order to address liquidity problems for other Micro Credit Institutions in the similar district/city; and

f. Conducting business outside business activities referred to in Article 11 paragraph (1).

In addition, to the matters described above, the coverage area of a Microfinance Institution is quite limited, which is located in an area of the Village, District, or Regency/ City. As for the coverage area is tailored to the business scale of Microfinance Institutions stipulated in Government Regulation.

As described above, the existence and role, as well as the function of LPD as a form of micro-finance institutions is important in improving the local economy. The enactment of Act No. 1 of 2013 on Micro Finance Institutions strengthened the position of LPD as microfinance institutions. To that end, the need for strengthening of LPD continuously and organizational in order to grow in various regions in Indonesia, as well as the Government support to open financial access and do not involve foreign intervention.

\section{CONCLUSION}

Rural Credit Institutions (LPD) is growing rapidly in the province of Bali. Although, various bank financial institutions, both commercial and credit banks are scattered and side by side in running the business, LPD can survive and have its own market share. The advantage of LPD rests on the coverage 
area of operations and operational activities in accordance with Pakraman village.

The success of LP) is the result of the concept of the establishment and management is obtained from local wisdom and Balinese cultural based on solidarity, kinship and cooperativeness. Although, the idea of establishing LPD comes from Bali Local Government (Governor Prof IB Mantra), but actually the idea was obtained of something that has evolved as a culture and local wisdom of Bali. That is, the idea of LPD is rooted in the customs and culture of Bali.

The cause of the success of LPD is also derived from the pattern of communitybased management with values of family and cooperativeness in the frame of the customs and culture of Bali. Communities in Pakraman be the owner and manager of LPD whose conducting duties and functions in commitments to achieve prosperity and progress together. This commitment that never failed to make a change in society and local wisdom should always be maintained by other regions in Indonesia.

\section{BIBLIOGRAPHY}

Dahlan Siamat. (2005). Manajemen Lembaga Keuangan, Kebijakan Moneter dan Perbankan. Fifth editions. Jakarta: Faculty of Economics University of Indonesia.

Dewi Wulansari. (2010). Hukum Adat In- donesia (Suatu Pengantar). Bandung: Refika Aditama.

I Nyoman Nurjaya et. al. (2011). Landasan Teoritik Pengaturan LPD (Sebagai Lembaga Keuangan Komunitas Masyarakat Hukum Adat Bali. Denpasar: Udayana University Press.

Konichi Ohmae. (1995). The End of the Nation State the Rise of Regional Economics. London: Harper Collins Publishers.

Muhammad Adlin Sila. (2010). "Lembaga Keuangan Mikro dan Pengentasan Kemiskinan: Kasus Lumbung Pitih Nagari di Padang." Jurnal Sosiologi Masyarakat FISIP-UI. Vol . 15, No. 1. Peter S. Rose. (1997). Money and Capital Markets. Financial Institution and Instruments in a Global Marketplace, $6^{\text {th }}$ Editions. Texas A \& M University.

Soerojo Wignjodipoero. (1983). Pengantar dan Asas-Asas Hukum Adat. Jakarta: Gunung Agung.

\section{Internet Sources:}

Ampenan News. Quoted from website: http://ampenannews.com/eksistensibudaya-indonesia-dalam-arus-globalisasi/. Accessed on 24 November 2015.

LPD Bali. Available online from website: http://lpd-bali.com/category/profil/ tentang/. Accessed on 27 November 2015. 